\title{
Seraphin Accepts MRS/OSA Fellowship Position with Sen. Lieberman
}

Arun Seraphin, the Materials Research Society/Optical Society of America Congressional Science and Engineering Fellow for 1999-2000, has accepted a position with Senator Joseph Lieberman (D-Conn.). Seraphin will be working on civilian and defense research and technology issues, including funding and oversight of federal agencies. He will also assist with technical issues associated with defense and proliferation and work with industry and non-government groups on national science and technology initiatives.

Seraphin said, "Senator Lieberman is a respected national policymaker in science and technology. He clearly has a strong desire to increase the government's commitment to science and technology both in fundamental and applied research and directed toward both commercial and defense needs. His commitment is evident from his leadership on the bill to double $R \& D$ funding as well as the Defense Innovation Provisions within the Defense Authorization Act. I see a real opportunity in this office to learn how good S\&T policy is made and to try to contribute to that."

The Defense Innovation Provisions attempt to restructure defense research and development planning and organization in order to improve U.S. ability to develop the technologies needed to meet the new national security challenges of the post-Cold War world. For more information on doubling R\&D funding, see MRS Bulletin, December 1998, pp. 9-10 and August 1998, p. 14.

Previous MRS/OSA Congressional Fellows Merrilea Mayo (1998-1999) and Kelly Kirkpatrick (1995-1996) also worked in Sen. Lieberman's office. Congressional Fellows Michal Freedhoff (1996-1997) did her tenure with U.S. Representative Edward J. Markey (D-Mass.) and Brian Holloway (1997-1998) did his with Sen. John D. Rockefeller (D-W.Va.). MाRs

\section{Access the Materials Research Society Public Affairs Website for links to Policies in Science and Technology www.mrs.org/pa/policy/

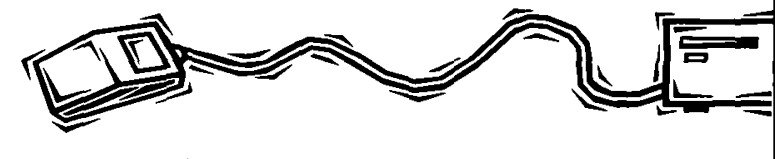

\section{Max-Flux ${ }^{\mathrm{TM}} 100$ Optics for X-ray Diffraction}

Osmic's expanded line of Max-Flux ${ }^{\mathrm{TM}} 100$ optics for XRD now available for

\section{Applications}

Thin-Film Analysis

Reflectometry

High Resolution X-ray Diffraction

Stress / Strain Measurement

Phase Analysis

Texture Analysis

Point-defect analysis

And more

\section{Benefits}

Reduction of sample displacement errors

Enables testing of irregularly shaped samples

Increased Resolution

Higher Flux

Lower Background

\section{Ti, Cr, Co, Cu, W-Lb, \& Mo optics}

